Bond University

Research Repository

\title{
Book Review: Fairy-Tale Films Beyond Disney: International Perspectives
}

\author{
Mitchell, Marilyn
}

Published in:

Media International Australia

DOI:

$10.1177 / 1329878 \times 18775135 i$

Licence:

Other

Link to output in Bond University research repository.

Recommended citation(APA):

Mitchell, M. (2018). Book Review: Fairy-Tale Films Beyond Disney: International Perspectives. Media International Australia, 168(1), 186-186. https://doi.org/10.1177/1329878X18775135i

\footnotetext{
General rights

Copyright and moral rights for the publications made accessible in the public portal are retained by the authors and/or other copyright owners and it is a condition of accessing publications that users recognise and abide by the legal requirements associated with these rights.
}

For more information, or if you believe that this document breaches copyright, please contact the Bond University research repository coordinator. 
Jack Zipes, Pauline Greenhill, and Kendra Magnus-Johnston (eds), Fairy-Tale Films Beyond Disney: International Perspectives. New York; London: Routledge, 2016; xviii + 355pp. ISBN: $9780414709309, \mathrm{~A} \$ 60.79$.

A valuable resource for anyone interested in fairy-tale films, the edited volume Fairy-Tale Films Beyond Disney continues discussion of the historical and national development of such films begun in Jack Zipes' (2011) The Enchanted Screen. In Beyond Disney, "fairy tales concern the fantastic, the magical, the dark, the dreamy, the wishful, and the wonderful" ( $p$. xiii), and may be of oral (e.g. spoken at different times and places) or literary (e.g. written by identifiable authors) origin. Films adapted from such sources may be made for television or cinema release, or direct to DVD; contain live action or animation; or be short or feature length. The book aims to give international perspectives on such films, to show important, creative alternatives to those produced by Disney.

The book contains 20 chapters of which the first three cover transnational issues. The remaining 17 chapters cover films from different places, specifically films from Europe (the UK, France, Germany, Italy, Scandinavia, Russia, the Czech Republic and the Slovak Republic, and Poland), Asia (Japan, People's Republic of China, India, and Korea), and postcolonial Africa, Australia, Canada, Latin America, and America. In total, 924 films are discussed. To provide a taste of the book, Zipes' Chapter 1 considers why the twenty-first century has experienced a global "tsunami" of fairy-tale films. Two reasons given are that fairy-tales can be adapted to present diverse points of view (e.g. feminist) and achieve different purposes (e.g. make social and political comments), which encourage the public to develop their imaginations. Chapter 1 also discusses the formula for a "well-made" Disney fairy-tale film, which is based upon the work of nineteenth-century writer, Augustin-Eugène Scribe. 
Chapter 2 by Kendra Magnus-Johnston discusses films that focus upon the lives of fairy-tale authors and film directors including Hans Christian Andersen, Charles Perrault, the Brothers Grimm, J. M. Barrie, P. L. Travers, George Méliès, and Walt Disney. Largely, the films are constructed as fairy-tales of the authors' lives although some remain closer to reality than others.

Chapter 3 by Sofia Samatar considers film adaptations of $A$ Thousand and One Nights, which were tales told originally in India, Persia, and Arab countries. Film adaptations may revolve around Shahrazad herself telling one or more of the tales, or a single tale such as Ali Baba and the Forty Thieves. Samatar criticises most adaptations as being simply spectacles of the Other, which in this case is the exotic, and as aiming to entertain rather than help audiences see the world in new ways.

All the nationally-oriented chapters offer new perspectives on fairy-tale films. For example, the French chapter discusses how fairy-tale films emphasise artistic experimentation and have been part of French cinema since its beginning, the Scandinavian chapter discusses fairy-tales with a Christmas focus and presents female authors, and the Australian chapter discusses how the country's fairy-tales began developing late (in the 1970s) and typically focus on lost children as symbols of anxiety over Australian identity. This book offers a wonderful place from which to learn more about international fairy-tale films.

Marilyn Mitchell

Bond University, Australia 